\title{
NUTRITION IN AGRICULTURAL DEVELOPMENT: LAND SETTLEMENT IN COAST PROVINCE, KENYA
}

\author{
JAN HOORWEG $^{12}$, DICK FOEKEN $^{1}$, WIJNAND KLAVER ${ }^{13}$, WALTER \\ OKELLO $^{4}$ and WILLEM VEERMAN ${ }^{1}$ \\ ${ }^{1}$ African Studies Centre, P.O. Box 9555, 2300 RB Leiden, The Netherlands; \\ ${ }^{2}$ Department of Human Nutrition, Agricultural University, Wageningen, The \\ Netherlands; ${ }^{3}$ International Agricultural Centre, Wageningen, The Netherlands; \\ ${ }^{4}$ Food and Nutrition Planning Unit, Ministry of Planning and National \\ Development, Nairobi, Kenya
}

(Recelved May 9, 1994, in final form October 15, 1995)

\begin{abstract}
This study concerns land settlement in Coast Province, Kenya, that occurred between 1960-1970 and the effects on later household income, food production and nutrition Household surveys were conducted among tenants in different settlement schemes and among the population in rural comparison locations In all aspects studied, the settlement tenants were better off than the rural population Further analysis indicated that the nutritional improvements can only partly be attributed to increases in food production and agncultural income Income from employment was also higher than that of the rural comparison population and this must also have contributed to the improvements Households with large farms generally realized larger incomes but also had much larger families and food consumption, and nutritional status of young children was lower among these households

It is concluded that the land distribution had a positive influence on household income and nutritional conditions The relation of farm size and household well-being, however, was not straightforward, being confounded by differences in family size and by the frequency of off-farm employment The fact that the households with the highest incomes did not show the most favourable nutritional conditions demonstrates, again, the need to include social and nutritional indicators in the evaluation of rural development projects
\end{abstract}

KEY WORDS Agricultural development, employment income, farm income, food consumption, household income, Kenya, land distribution, nutritional status, rural development, settlement schemes

\section{INTRODUCTION}

\section{Nutrition in Agricultural Development}

Agricultural development is one of the main priorities for the countries of SubSaharan Africa. To increase agricultural production, supportive agricultural policies are needed as well as improvements in farming practices, including changes in land distribution and ownership. The expectation was that such changes would lead to increased production which, in turn, would result in increased incomes and higher living standards. However, evidence emerged that increases in productivity may actually be realized at the expense of the living conditions of the farming population (Fleuret and Fleuret, 1980) There has long been concern about the effects of

Correspondence Dr Jan Hoorweg, African Studies Centre, P O Box 9555, 2300 RB Leiden, THE NETHERLANDS 
commercialisation of agriculture on poverty and nutrition in developing countries. Opponents have argued that land and labour are taken away from food production, that income gains tend to be skewed and do not reach the poor and that there are adverse economic developments such as possible rises in food prices. Proponents have pointed to the comparative economic advantage of cash crops for many tropical countries, the income opportunities that are created for smallholders, and also the employment opportunities for the landless (Pinstrup-Andersen, 1985). Effects on income and employment, on food consumption and on health and nutrition have been investigated (Braun and Kennedy, 1994). Agricultural development may have positive as well as negative consequences for food and nutrition conditions depending on the social environment in which it occurs and the manner in which people utilize different sets of resources. Hence the need for studies on different kinds of agricultural development.

Distribution of land is often regarded as an important way to improve food security and alleviate malnutrition. Kenya, despite its image as a fertile country is, in fact, short of good agricultural land (Ruigu, 1987). Only $20 \%$ of the land area consists of high and medium potential lands with good to fair prospects for crop production and intensive livestock activities. Many rural areas in Kenya are densely settled, many people have uncertain access to land and many are living on small or very small plots (Jazairy, Alamgir and Panuccio, 1992). The rapid population growth, of about $3.4 \%$ per annum, necessitates substantial increases in food production together with increases in the production of export crops. Production increases will depend mainly on the possibilities of increasing yields per hectare, and of bringing remaining, often marginal, areas under cultivation (Government of Kenya, 1986).

In many developing countries settlement schemes have been established with the aim to settle displaced persons or to provide landless families and squatters with land and a livelihood. In addition, settlement schemes are often regarded as a means to increase food production and cash crop cultivation and to promote rural development through optimal utilization of physical and human resources (Chambers, 1969; Hinderink and Sterkenburg, 1986). Melville (1988) reviewed 31 studies concerned with land availability and nutritional conditions in different continents. There generally exists a positive relationship between landownership and nutritional status, if and when a comparison is drawn with landless households. However, there is no consistent relationship between the size of the farm and nutritional conditions. The reviewer points to the role of other factors such as off-farm employment and food purchases that are also important for household nutrition.

Because of the great demand for land, the Kenyan government, since independence in 1963, has parcelled out tracts of land among smallholder tenants. This involves the division of former European-owned farms in the fertile highlands, but also large areas in Coast Province, with a lesser agricultural potential.

\section{Coast Province, Kenya}

Coast Province is the third area of population concentration in Kenya with more than 1.8 million people at the time of the census in 1989 (Central Bureau of Statistics, 1994). The economic development of the region has not kept pace with that of central and western Kenya due to a combination of climatic, economic and social factors.

Rainfall in Coast Province has a bi-modal distribution: the long rains start in April and the short rains in October/November The climate is hot and dry from January to end-March, when daily temperatures average more than $30^{\circ} \mathrm{C}$. The fertility of the land 
tends to be low because most soils are chemically poor (Boxem, Meester and Smaling, 1987). The coastal plain along the seashore and the adjoining uplands have potential for food and cash crop production. Further inland conditions become drier and allow for the mixed farming of food crops and livestock. The sparsely populated hinterland is more suitable for ranching (Jaetzold and Schmidt, 1983; Waaijenberg, 1994).

Previously, the economy was primarily dependent on agriculture, the cultivation of food crops (cereals, cassava) and tree crops (coconut palms, cashew trees and, to a much lesser extent, mango and citrus). The seasonal character and low reliability of rainfall, however, severely restrict the scope and productivity of agriculture while the short rains are often insufficient for a second crop. Drought conditions are not uncommon (Herlehy, 1984; Kliest, 1985; Foeken and Hoorweg, 1988; Waaijenberg, 1993). Wage employment has become increasingly important although, compared with central and western Kenya, the industrial and services sectors have shown only slow development, the tourist sector being an exception (Ministry of Environment and Natural Resources, 1984a; 1984b).

Coast Province generally ranks low on development indicators such as infant mortality, childhood malnutrition, and enrollment of girls in primary education. Estimates place the incidence of rural poverty at $40 \%$ of the households or more, which is higher than in Kenya as a whole (Central Bureau of Statistics, 1983; 1988; UNICEF, 1984; Greer and Thorbecke, 1986; Foeken et al., 1989).

The main population group is the Mijikenda, who used to occupy the upland ridges in fortified villages, kayas, but who changed to a more dispersed form of habitation in the nineteenth century (Spear, 1978). In the early 19th century the lands in the coastal plain were mainly in the hands of the resident Arab and Swahili populations, who developed large plantations (Salim, 1973). After the abolition of slavery this plantation economy declined and many Mijikenda joined ex-slaves living on unproductive plantations (Cooper, 1981). Migration from the coastal inland to the coastal plain increased further in the 1960s and many people settled on unused parts of estates or on state-owned land. It is these lands that were first selected for distribution among smallholders in the post-independence period since 1963.

Most of the settlement schemes in Kenya fall into two categories, namely schemes with individual holdings consisting of independent smallholder farms, and schemes with scheduled production, also consisting of small farms but with the obligation to cultivate cash crops with certain farming restrictions and compulsory marketing arrangements. The schemes in Coast Province belong to the first category and consist of smallholdings cultivated by the tenants according to their own interests and initiatives. Government intervention has been limited to physical planning, scheme layout and the selection of the settlers. Agro-support and social services are generally similar to those supplied to the farming population in general although, for a number of years, there was a donor programme to support settlement tenants in Kilifi District. Contradictory opinions have been voiced about the conditions at the settlement schemes. The tenants were either regarded as the lucky few in a country beset by land problems, or as people left to their own devices without suitable farming experience and given too little development assistance (Leys, 1975; Heyer and Waweru, 1976)

In Kenya, the aim of settlement policy has generally been to provide enough land so that the farm can sustain a family. In Coast Province, 12 acres $(=4.8 \mathrm{ha})^{\mathrm{a}}$ were regarded as the necessary farm size, although this has been a subject of discussion, and in some cases smaller plot sizes were decided on. At the time of study, there

${ }^{\circledR} 1$ hectare $=2.5$ acres 
were 14 settlement schemes in Coast Province with a total of about 7-8,000 settler households. By the time of completion, the schemes were planned to cover a total of $100,000 \mathrm{ha}$ and to include some 12,750 settlers and their families. All schemes are located in Kilifi and Kwale Districts, with the exception of Lake Kenyatta Settlement Scheme in Lamu District. The schemes are so-called Haraka schemes that are, in principle, meant for landless and unemployed people. Since these requirements were usually not strictly upheld, many tenants owned (small) plots elsewhere before joining and many had some kind of employment. Also, some tenants have sold off their plots or parts of their plots to one or more buyers. Others have managed to acquire more land in the schemes or own parcels of land elsewhere.

The objective of the present study was to assess conditions among tenants on smallholder schemes in Coast Province with respect to the two issues mentioned. ${ }^{b}$ First, what does land ownership imply for people who have been landless in the past or who have owned little land until this. Household income and nutritional conditions of scheme tenants are compared with others who have not been given land. Second, is there a relationship among farm size, household prosperity and nutritional conditions. To address this question, tenant households with different farm sizes are compared. Initial results were reported in Hoorweg et al. (1991) with more details on the schemes and including the results of an atypical scheme not included in the present paper. A separate paper will discuss the schemes as examples of non-intensive rural development.

\section{METHODS}

\section{Design and Sampling Procedure}

Three major schemes were selected for study that had been established in 1962, 1968 and 1969 respectively (Ukunda, Mtwapa and Roka-East; see map, Figure 1). Two schemes are situated in Kilifi District; one in Kwale. They are located in the coastal plain, and tenants were issued identical plot sizes. Together they accounted for a third of all settler plots in the two districts.

For comparison purposes, results were available from a household survey conducted among the rural population in the two districts during the same period using the same methods and with the help of the same field assistants (Foeken et al., 1989; Niemeijer, Foeken and Klaver, 1991). This study covered six research areas from which three locations were selected for comparison, one for each settlement scheme, situated in the same district and the same agro-ecological zone. The locations present a picture of the rural population in the areas where the schemes are situated and from which many settlers originate.

The sampling unit was the household, defined as a group of people who reside together under one or more roofs within a single compound, who are answerable to the same head and share a common source of food. People without access to farmland were excluded. ${ }^{c}$ In the settlement schemes, plots without households

${ }^{\mathrm{b}}$ The settlement study is part of a larger research programme looking into rural conditions in the coastal lowlands (Hoorweg, Kliest and Niemeijer, 1988; Foeken and Hoorweg, 1988; Foeken et al., 1989; Niemeijer, Focken and Klaver, 1991; Leegwater, Ngolo and Hoorweg, 1991; Oosten, 1989; Peters and Niemeijer, 1987; Maas and Hekken, 1991; Hoorweg, 1993).

'This nearly always concerned people such as teachers, agricultural workers who had rented rooms/houses in the area, or guardsmen hired to protect the plot from squatter occupation. 


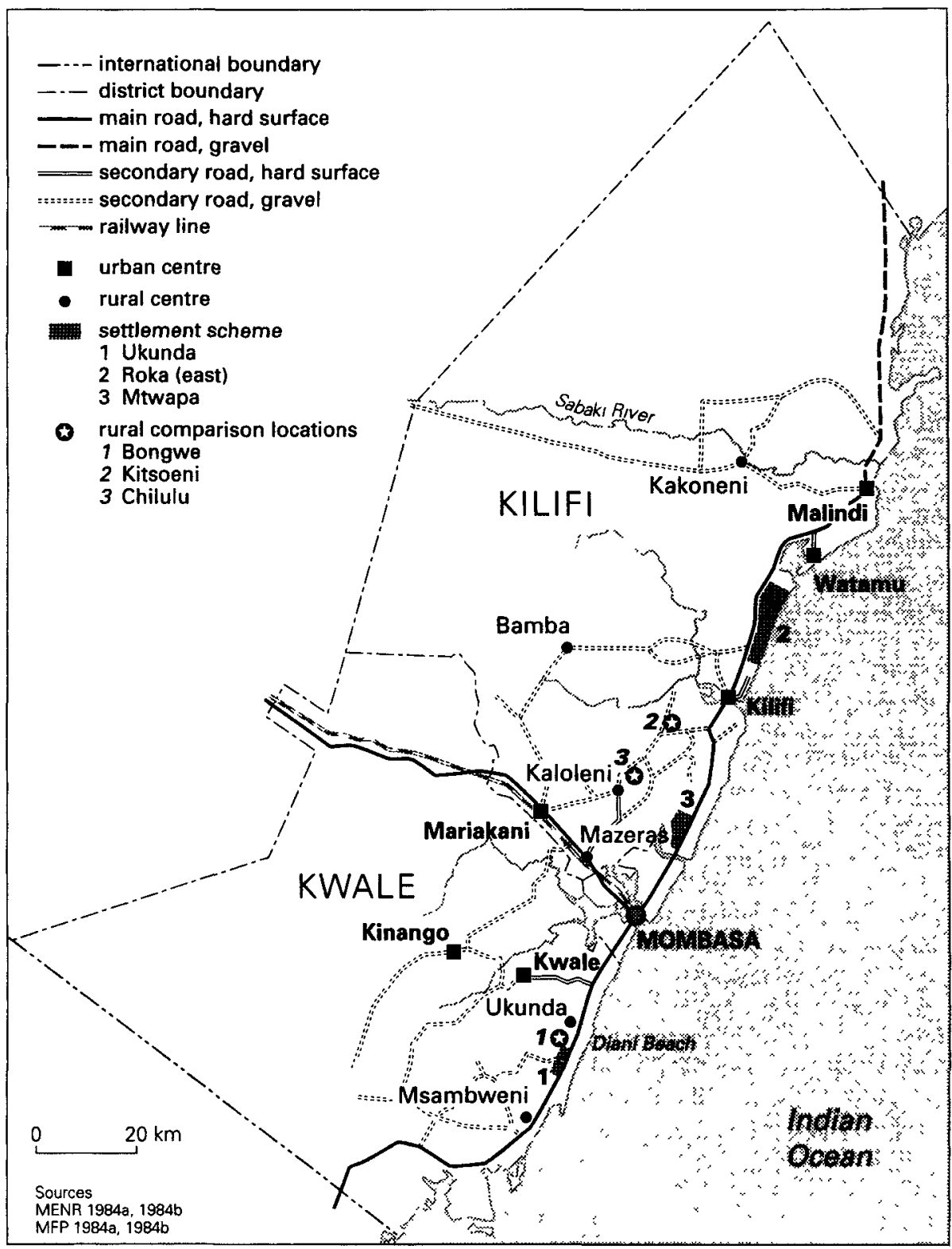

FIGURE 1 Map of Coastal Kenya showing Districts studied.

actually living there were passed over. In the cases in which a plot was occupied by more than one household, all households were included in the sample.

During the period August 1985 to September 1986, an accruing sample of 300 tenant households were visited and interviewed in the course of five survey rounds. Each household was visited once. During each survey round sixty households were 
visited (twenty per scheme, selected in random clusters of ten) so that seasonal variations were evened out over the year. Information on subsistence crop production over the past agricultural year was collected only for the households that were visited in the immediate post-harvest period, namely during the second survey round ( $\mathrm{N}=60$; twenty in each scheme).

The rural comparison population consisted of 150 households (50 in each of the three locations), each visited five times during the same time period (between June 1985 and November 1986). Information on household income and subsistence crop production in this comparison group was collected during the first and second survey round. Food consumption and nutritional status were recorded during all rounds and the results presented here consist of the averages over five rounds.

\section{Data Schedule}

The data schedule covered living conditions of the households, household size, demographic and employment characteristics of the household members, farm characteristics, household food consumption, and the nutritional status of adult women and children. The information on living conditions consisted of housing characteristics and sanitation facilities. The demographic particulars included sex, age, marital status, education and occupation. Employment was specified by type and period of employment together with a corresponding income classification. The farm characteristics were concerned with annual crops, perennials, tree crops, and livestock.

Food consumption was estimated with a 24-hour recall of all food prepared in the compound during the day prior to the interview. In households with more than one kitchen, food preparation was recorded for each kitchen. The women concerned were questioned about all the foods and drinks they had prepared or served in the course of the previous day. Starting with the first dish of the day all subsequent dishes (including drinks and snacks) were covered. The women were further asked to indicate the cooking procedures and to demonstrate the quantities of the different ingredients used before preparation and, if needed, after preparation. Volumes of household measures were estimated using maize kernels as a volumetric dummy that were poured into plastic measuring jars. In the case of leftovers from meals, the proportion of the food that had not been eaten was estimated and subtracted. ${ }^{d}$ For each ingredient the assistant further inquired whether it was home-produced (subsistence) or from another source, which nearly always meant that the food had been purchased. The food composition table of Platt (1962) was used to calculate energy and protein contents.

Nutritional status was assessed by means of anthropometry. For children, aged 6 months to 10 years, height and weight were measured (settlements $N=733$; rural population $N=472$ ). For children under two years weights were measured with a Salter 235 scale (maximum $25 \mathrm{~kg}$. with an accuracy of $100 \mathrm{~g}$.) and heights were measured in supine position on a wooden length board. For older children weights were measured with a Teraillon digital scale (maximum $135 \mathrm{~kg}$. with an accuracy of 200 g.) and heights were measured in upright position using microtoises fixed to a standing metal rod with a wooden footpiece.

${ }^{d}$ In some households visitors participated in meals, in other households some members had meals while visiting a friend or relative. A check in one of the companion studies revealed no systematic bias from this source: both visitors and outside meals cancel each other out statistically (Niemeyer, Foeken and Klaver, 1991). 


\section{Data Analysis and Presentation}

Household size was calculated in terms of consumer units (cu): individuals were weighted on the basis of their estimated nutritional requirements according to sex, age and assumed activity level as given by WHO (1985). One consumer unit equals a reference adult male of 20-29 years requiring an estimated 2,960 kcal per day. This procedure, by its nature, corrects for age-sex differences in household composition.

Food self-sufficiency was calculated on the basis of the reported harvests of cereals, beans, cassava and banana in the agricultural year 1985/86, with the assumption that $75 \%$ of total energy requirements should be met by these staple foods.

Household income was calculated in shillings/household/year ${ }^{\mathrm{f}}$ and includes the net value of cash crop production (excluding subsistence food crops); livestock proceeds; and wages from various forms of employment corrected for worker residence (if not fully resident the wage income was only partly calculated towards the household income).

Nutritional status was expressed as percentages of the international reference values for height-for-age, weight-for-height and weight-for-age (WHO, 1983).

The results of the comparison of the settlement tenants with the rural population living outside the schemes are discussed. Next, tenants with different farm sizes are compared (0-2.9, 3.0-11.9, 12.0, and 12.1+ acres, respectively). Differences between groups were statistically tested ( $t$-test and chi-square in the case of two-group comparisons; analysis of variance in case of more groups); the results are given in the tables with the degrees of freedom and level of significance.

\section{RESULTS AND DISCUSSION}

\section{Living Conditions}

Household size in the schemes is only slightly larger than among the rural comparison population (Table I). About $30 \%$ of the households in both samples

TABLE I

Characteristics of study groups in Coastal Kenya

\begin{tabular}{lcc}
\hline & $\begin{array}{c}\text { Settlement } \\
\text { Schemes }\end{array}$ & $\begin{array}{c}\text { Rural } \\
\text { Sample }\end{array}$ \\
\hline Sample composition & & \\
$\quad$ Number of households & 299 & 150 \\
Av.no.people/h hold & 8.8 & 8.4 \\
$\quad$ Av.no.consumer units/h hold & 5.8 & 5.4 \\
Living conditions & & \\
$\quad$ Av.no.people/room & 2.4 & 2.6 \\
Latrine present & $30 \%$ & $54 \%$ \\
\hline
\end{tabular}

${ }^{\mathrm{c}}$ That is, 2,220 kcal per cu per day. This assumption was later corroborated by the results of the survey in six locations (Niemeyer, Foeken and Klaver, 1991). The contribution of the staple foods equalled $2,166 \mathrm{kcal}$, being $84 \%$ of the actual intake and $73 \%$ of the estimated requirements.

'During the period of study the exchange rate of the Kenya shilling against the US dollar varied from 18:1 to $16: 1$. 
consist of nuclear families, nearly $10 \%$ are female-headed households and $60 \%$ are extended households of various kinds. It appears that the two samples are quite comparable in terms of general living conditions. There are differences in sanitary conditions, but these do not favour the settlement population.

\section{Household Resources}

Rural households have two major means of production: land and labour. Table II shows that the two samples clearly differ in land availability. The standard plot issued at the start of the schemes was 12 acres ( $4.8 \mathrm{ha}$ ) and the average farm size in the schemes is much larger than among the comparison households in the same agroecological zones, 11.4 acres versus 4.9 acres. However, considerable differentiation in landownership has occurred since then; only half the households still possess the same plot size initially issued, while one third of the tenants own less than that. Among the rural sample less than $10 \%$ had farms of 12 acres or more; half of the farms are less than 12 but more than 3 acres; the rest were less than 3 acres.

Labour is needed on the farm but also used in off-farm employment ranging from regular jobs (with government or industry) to casual labour (for example, in the building industry or on other farms) and self-employment (as traders or food sellers, etc). In the settlement schemes, about $40 \%$ of the adult population is engaged in offfarm employment ( $55 \%$ of the men and $26 \%$ of the women). Among the rural sample less than $30 \%$ of the adults had some form of employment $(45 \%$ of the men and only $11 \%$ of the women). The majority of households report income from offfarm employment ( $85 \%$ and $67 \%$, respectively).

\section{Household Income}

On average, the income from agriculture-cash crops and livestock-in the schemes is about five times that among the rural comparison group (Table III). This difference is mostly due to the income from tree crops, since the income from livestock in the schemes is generally low.

The income from off-farm employment by workers in the settlement schemes was substantially higher than that earned in the comparison locations. This is the result of

TABLE II

Household resources of study groups in Coastal Kenya

\begin{tabular}{lcc}
\hline & $\begin{array}{c}\text { Settlement } \\
\text { Schemes } \\
\%\end{array}$ & $\begin{array}{c}\text { Rural } \\
\text { Sample } \\
\%\end{array}$ \\
\hline $\begin{array}{l}\text { Farm size (acres) } \\
0.0-2.9\end{array}$ & 14 & 41 \\
$3.0-11.9$ & 20 & 50 \\
12.0 & 47 & \} \\
$12.1+$ & 19 & \} 9 \\
$\begin{array}{l}\text { Frequency off-farm employment (o.f.e.) } \\
\% \text { maie adults with o.f.e. }\end{array}$ & 55 & 45 \\
\% female adults with o.f.e. & 26 & 11 \\
Employment income & & \\
$\quad$ Households with income from o.f.e. & 85 & 67 \\
\hline
\end{tabular}


TABLE III

Income composition of study groups in Coastal Kenya (sh/h hold/year, corrected for worker residence, not including food crops)

\begin{tabular}{lcc}
\hline & $\begin{array}{c}\text { Settlement } \\
\text { Schemes } \\
(\mathrm{N}=299)\end{array}$ & $\begin{array}{c}\text { Rural } \\
\text { Sample } \\
(\mathrm{N}=150)\end{array}$ \\
\hline Cash crops & 4,718 & 829 \\
Livestock & 488 & 157 \\
Regular employment & 5,497 & 2,764 \\
Self-employment & 3,895 & 1,767 \\
Casual and irregular labour & 1,151 & 813 \\
$=$ total income & 15,749 & $6,328^{\mathrm{a}}$ \\
$=$ income/consumer unit & 3,373 & $1,353^{\mathrm{b}}$ \\
$\quad$ (standard deviation) & $(3,457)$ & $(1,645)$ \\
${ }^{\mathrm{a}} t=7.77 ; \mathrm{df}=447 ; \mathrm{p}<0.001$. & & \\
${ }^{\mathrm{b}} t=6.78 ; \mathrm{df}=447 ; \mathrm{p}<0.001$. & & \\
\hline
\end{tabular}

higher incomes from regular employment but also from self-employment, and because workers in the schemes more often reside at home and their wages are fully included in the household income.

The income of the households averages somewhat more than sh.15,700 in the schemes, compared with about sh.6,300 among the rural sample; in both groups, the income from employment accounts for two-thirds or more of the resource base.

In the rural comparison group about $40 \%$ of the households fall below the food poverty line (sh. $1,000 / \mathrm{cu} / \mathrm{year})$, the necessary purchasing power for a household energy supply sufficient to assure daily survival but with minimal activities $(2,115 \mathrm{kcal} / \mathrm{male}$ adult/day $)$. This finding is quite similar to figures reported by Greer and Thorbecke (1986) based on data collected in 1975 and by the Central Bureau of Statistics (1988) on data collected in 1982. In the settlement schemes the number of households in such poor circumstances is much smaller, between 10 and $15 \%$.

\section{Food Self-Sufficiency}

In general, food production in the region is modest and not sufficient to meet the needs of the local population; 1985/86 was no exceptional year (Foeken et al., 1989). Nearly all farmers grow cereals. Maize is the main crop and some rice is cultivated. Sorghum and millet are hardly grown. There is little difference between the two groups in the amounts of cereals harvested. Cassava is also widely grown, but in the settlement schemes the number of plants is more than double that outside the schemes. In addition, small amounts of legumes and bananas are harvested in the schemes.

On average, in the settlement schemes staple food production was sufficient to cover about two-thirds of the energy intake that was expected to come from staple foods (Table IV). This is more than that among the rural comparison group in which the degree of food self-sufficiency was only $50 \%$, and food self-sufficiency of half the households is less than one third of the needs. Large amounts of staple foods have to be purchased because other ways of obtaining foods, such as hunting, gathering, or gifts, are of little importance. The actual contribution of home production to daily food consumption is even smaller, as is shown below. 
TABLE IV

Self-sufficiency in staple foods of study groups in Coastal Kenya

\begin{tabular}{lcc}
\hline & $\begin{array}{c}\text { Settlement } \\
\text { Schemes } \\
(\mathrm{N}=60) \\
\%\end{array}$ & $\begin{array}{c}\text { Rural } \\
\text { Sample } \\
(\mathrm{N}=150) \\
\%\end{array}$ \\
\hline $\begin{array}{l}\text { Average (s.d.) } \\
\text { (cereals, beans, cassava, banana) }\end{array}$ & $67(53)$ & $49(61)^{\mathrm{a}}$ \\
$\begin{array}{l}\text { Distribution (\%) } \\
00.0-33.2\end{array}$ & & \\
$33.3-66.6$ & 28 & 49 \\
$66.7-99.9$ & 32 & 33 \\
$100.0+$ & 22 & 5 \\
& 18 & $12^{\mathrm{b}}$ \\
${ }^{\mathrm{a}} t=2.09 ; \mathrm{df}=208 ; p=0.04$. & 100 & 100 \\
${ }^{\mathrm{b}} \mathrm{X}^{2}=17.06 ; \mathrm{df}=3 ; p<0.001$. & & \\
\hline
\end{tabular}

\section{Food Consumption}

Diets in Coast Province consist, like those in the rest of Kenya, first and foremost of maize meal mainly in the form of ugali (maize paste) or uji (thin maize porridge). Virtually all households consume at least one maize dish a day (on average more than $2 \mathrm{~kg}$. dry maize equivalent a day). Next in daily importance are cassava, green leaves and fish, consumed in much smaller amounts than maize meal. On average, only $200 \mathrm{ml}$. of milk are consumed per household per day. Tomatoes and coconuts also are eaten but in small amounts and they serve mostly as flavourings. The same is the case with fats, oils and sugar.

The settlement households tend to have a somewhat more varied diet, in which maize and green leaves are less predominant than among the rural comparison group; they eat cassava and fresh fish more often and in larger amounts. Coconuts, tomatoes, fats, oils and sugar also are eaten more frequently, although not in larger amounts.

The settlement population has an average intake of about $2,800 \mathrm{kcal} / \mathrm{cu}$, which is only $5 \%$ below the estimated requirement of $2,960 \mathrm{kcal} / \mathrm{cu}(\mathrm{WHO}, 1985)$. The figure for the rural sample is lower, about $2,450 \mathrm{kcal} / \mathrm{cu}$. $17 \%$ below requirements and 350 kcal below that of the settlement groups (Table V). ${ }^{\mathrm{g}}$

Consequently, on any given day a large number of households $(60$ and $70 \%$ respectively) have intakes below the estimated requirements of $2,960 \mathrm{kcal} / \mathrm{cu}$ per day. In the absence of information on day-to-day variations, this almost certainly gives an overestimate of the prevalence of energy inadequacy. Nevertheless, it is noteworthy that, on any given day, $25 \%$ of the households have an energy consumption below $70 \%$ of energy requirements, or $2,100 \mathrm{kcal} / \mathrm{cu}$. This compares very well with an estimate of $15 \%$ of households with an income below the food poverty line, a calculation that was also based on a figure of $2,100 \mathrm{kcal} / \mathrm{cu}$ but that represents a one-year period instead of a one-day recall.

${ }^{8}$ The standard deviation of energy and protein intake is quite high, in the order of $40-50 \%$ of the mean value in the settlements group and $30-35 \%$ in the rural sample. The coefficient of variation in the rural sample is lower because it is based on the average of five recalls. The large variation of recall data is well known and is always reason for concern, but the method is accepted to be well suited for group comparisons. 
TABLE V

Food consumption of study groups in Coastal Kenya

\begin{tabular}{|c|c|c|}
\hline & $\begin{array}{l}\text { Settlement } \\
\text { Schemes } \\
(N=290)\end{array}$ & $\begin{array}{c}\text { Rural } \\
\text { Sample } \\
(\mathrm{N}=149)\end{array}$ \\
\hline $\begin{array}{l}\text { Energy and protein intake } \\
\text { Av. energy intake; } \mathrm{kcal} / \mathrm{cu} \text { (s.d) } \\
\text { Av. protein intake; } \mathrm{g} / \mathrm{cu} \text { (s.d) }\end{array}$ & $\begin{array}{c}2,789(1150) \\
74(36)\end{array}$ & $\begin{array}{c}2,499(742)^{\mathrm{b}} \\
65(23)^{\mathrm{c}}\end{array}$ \\
\hline $\begin{array}{l}\text { Origin energy intake }(k c a l / c u) \\
\text { Subsistence } \\
\text { Purchases }\end{array}$ & $\begin{array}{c}822(29 \%) \\
1,967(71 \%)\end{array}$ & $\begin{array}{c}791(32 \%) \\
1,658(68 \%)\end{array}$ \\
\hline
\end{tabular}

The protein intake is about $70 \mathrm{~g} / \mathrm{cu} /$ day in both populations, which is considerably above the recommended value of $50 \mathrm{~g}$. The recommended protein intake was realized in more than $70 \%$ of the households. Whatever difference there is in protein intake can be explained by variations in energy intake. In both groups, average protein intake equals $10.6 \%$ of total energy intake.

The settlement and rural populations draw similar amounts of energy from subsistence food (food grown on own farm), about $800 \mathrm{kcal} / \mathrm{day}$, roughly $30 \%$ of total intake in both groups. ${ }^{\text {h }}$ The difference in total energy intake between the two groups, noted above, comes from a large difference in the consumption of foods that are purchased, namely $1,950 \mathrm{kcal} / \mathrm{cu}$ versus $1,650 \mathrm{kcal} / \mathrm{cu}$, or $300 \mathrm{kcal}$. Their higher incomes apparently allow the settlement tenants to purchase more food and they procure chiefly maize meal, but also animal foods and sugar in greater amounts.

\section{Nutritional Status of Children}

Morbidity figures in the schemes differ little from the rural sample. There are small but consistent differences in weight-for-height (Table VI). The percentage of severely malnourished children, below $60 \%$ of reference weight-for-age, varies from 2 to $6 \%$ among the rural sample and is $2 \%$ or less in the settlements.

Although there are some malnourished children, as a group the settlement children have a better nutritional status. Differences in children in height-for-age between the settlements and the rural sample increase with age and are significantly different in the eldest age group. This points to a cumulative effect of environmental influences, namely the more consistent living conditions at the schemes based on more sufficient household resources. It is also probable that the pressure of infectious diseases is less in the older group and consequently the influence of environmental factors appears stronger.

${ }^{\text {h}}$ This percentage is less than could be expected from the degree of food self-sufficiency that was earlier calculated, but in this case the calculation is concerned with total energy requirements. There are indications, however, that not all of the subsistence food is indeed consurned, notably in the case of cassava (see Hoorweg et al., 1991). 
TABLE VI

Nutritional status of children in Coastal Kenya

\begin{tabular}{lcc}
\hline & $\begin{array}{c}\text { Settlement } \\
\text { Schemes }\end{array}$ & $\begin{array}{c}\text { Rural } \\
\text { Sample }\end{array}$ \\
\hline $\begin{array}{l}\text { Children reported ill durng past 14 days \% } \\
\text { 6-23 months }\end{array}$ & 62 & $68^{\mathrm{d}}$ \\
24-59 months & 47 & $50^{\mathrm{b}}$ \\
60-119 months & 37 & $38^{\mathrm{c}}$ \\
Chldren below $60 \%$ of weight-for-age \% & & \\
6-23 months & 2.3 & 2.5 \\
24-59 months & 1.3 & 2.1 \\
60-119 months & 1.6 & 5.3 \\
Average weight-for-height $(W-H)$ & & $93.4^{\mathrm{d}}$ \\
6-23 months & 94.5 & $92.2^{\mathrm{c}}$ \\
24-59 months & 93.3 & $91.1^{\mathrm{f}}$ \\
60-119 months & 92.8 & \\
Average height-for-age $(H-A)$ & & $93.4^{\mathrm{E}}$ \\
$6-23$ month & 93.2 & $91.9^{\mathrm{h}}$ \\
24-59 months & 92.8 & $91.7^{\mathrm{b}}$ \\
60-119 months & 93.1 & \\
\hline
\end{tabular}

\footnotetext{
${ }^{\mathrm{a}} \mathrm{N}=128 / 81$

${ }^{b} \mathrm{~N}=233 / 146$

$\mathrm{N}=372 / 244$

$t=0.87 ; \mathrm{df}=207 ; p=0.38$

${ }^{c} t=1.35 ; \mathrm{df}=377 ; p=0.18$

$\mathrm{f}_{\mathrm{t}}=2.90 ; \mathrm{df}=614 ; p=0.004$

$g_{t}=-0.21 ; \mathrm{df}=207 ; p=0.84$

${ }^{\mathrm{h}} t=1.83 ; \mathrm{df}=377 ; p=0.07$

$i=3.25 ; \mathrm{df}=614 ; p<0.001$
}

\section{Relationship with Farm Size}

The household income of settlement tenants increases quite strongly with farm size, being more than double on the large farms (Table VII). However, larger farms also have larger households, family size doubling as well. When income is adjusted for household size and calculated per consumer unit the relationship is different. Income is still highest on the very largest farms but is next highest on the very smallest farms. The income of the groups in between is lowest. The reason for this lies in income from off-farm employment.

The households on the smallest farms have little income from farming but have the highest income from employment (per consumer unit) of all four groups, particularly from regular employment. The household economy of this group is apparently directed towards employment and this has enabled them to acquire (small) plots from the original settlers. On the larger farms the household economy is directed more towards farming, the necessary labour being available because of the larger family size. Food self-sufficiency increases with farm size (Table VIII) and so does farm income--absolutely as well as relatively (but even in the households with large farms more than half the income is from employment; see Table VII).

Because of the covariation between farm size and household size, the results for energy intake must be interpreted with caution (Table VIII). In large households greater amounts of food need to be prepared but it is known that amounts per person 
TABLE VII

Household income and income composition at settlement schemes in Coastal Kenya

\begin{tabular}{lcccc}
\hline & \multicolumn{5}{c}{ Farm Size (acres) } \\
\hline & $\begin{array}{c}0-2.9 \\
(\mathrm{~N}=41)\end{array}$ & $\begin{array}{c}3.0-11.9 \\
(\mathrm{~N}=60)\end{array}$ & $\begin{array}{c}12.0 \\
(\mathrm{~N}=141)\end{array}$ & $\begin{array}{c}12.1+ \\
(\mathrm{N}=57)\end{array}$ \\
\hline $\begin{array}{l}\text { Consumer units (av) } \\
\text { Income (av) }\end{array}$ & 3.5 & 4.9 & 6.2 & 7.4 \\
$\quad$ sh/household & 9,782 & 13,070 & 15,560 & $23,328^{\mathrm{a}}$ \\
sh/consumer unit & 3,562 & 2,774 & 3,165 & $4,382^{\mathrm{b}}$ \\
Income composition (sh/consumer unit) & & & & \\
$\quad$ farm income & 238 & 946 & 1,052 & $1,876^{\mathrm{c}}$ \\
$\quad$ regular employment & 2,268 & 828 & 1,078 & $1,706^{\mathrm{d}}$ \\
$\quad$ self employment & 622 & 686 & 883 & $721^{\mathrm{e}}$ \\
$\quad$ casual and irregular empl & 433 & 314 & 152 & $80^{\mathrm{f}}$ \\
\hline
\end{tabular}

${ }^{\mathrm{a}} \mathrm{F}(3,295)=9.95 ; \mathrm{p}<0.001$

${ }^{\mathrm{b}} \mathrm{F}(3,295)=2.46 ; \mathrm{p}=0.06$

${ }^{\mathrm{c}} \mathrm{F}(3,295)=8.90 ; p<0.001$

${ }^{\mathrm{d}} \mathrm{F}(3,295)=3.22 ; p=0.02$

${ }^{e} \mathrm{~F}(3,295)=0.44 ; p=0.72$

${ }^{\mathfrak{f}} \mathrm{F}(3,295)=4.99 ; p<0.005$

TABLE VIII

Energy intake and nutritional status at settlement schemes in Coastal Kenya

\begin{tabular}{lcccc}
\hline & \multicolumn{4}{c}{ Farm Size (acres) } \\
\hline & $0-2.9$ & $3.0-11.9$ & 12.0 & $12.1+$ \\
\hline Food self-sufficiency (\%) & 46 & 66 & 68 & $78^{\mathrm{a}}$ \\
Energy intake & & & & \\
$\quad$ kcal/h hold & 10,055 & 14,334 & 16,006 & $18,817^{\mathrm{c}}$ \\
$\quad$ kcal/cons unit & 3,060 & 3,059 & 2,661 & $2,636^{\mathrm{d}}$ \\
Energy intake by origin (kcal/consumer unit) & & & & \\
$\quad$ subsistence & 795 & 705 & 891 & $795^{\mathrm{c}}$ \\
$\quad$ purchases & 2,265 & 2,354 & 1,770 & $1,841^{\mathrm{f}}$ \\
Nutritional status children (average height-for-age) & 94.8 & 94.2 & 93.0 & $92.2^{\mathrm{g}}$ \\
$\quad$ 6-23 months & 93.2 & 93.5 & 92.6 & $92.5^{\mathrm{h}}$ \\
$\quad 24-59$ months & 93.6 & 93.9 & 92.5 & $94.1^{1}$ \\
$\quad 60-119$ months & & & & \\
\hline
\end{tabular}

${ }^{\mathrm{a}} \mathrm{F}(3,56)=0.67 ; \mathrm{p}=0.57(\mathrm{~N}=8 ; 13 ; 22 ; 17)$

${ }^{\mathrm{b}} \mathrm{N}=38 ; 59 ; 138 ; 55$

${ }^{\mathrm{C}} \mathrm{F}(3,286)=7.31 ; \mathrm{p}<0.001$

${ }^{\mathrm{d}} \mathrm{F}(3,286)=2.73 ; \mathrm{p}=0.04$

${ }^{\mathrm{e}} \mathrm{F}(3,286)=0.61 ; \mathrm{p}=0.6$

${ }^{i} \mathrm{~F}(3,286)=3.94 ; \mathrm{p}<0.01$

${ }^{B} \mathrm{~N}=12 ; 26 ; 60 ; 30$

${ }^{\mathrm{h}} \mathrm{N}=12 ; 48 ; 110 ; 63$

$\mathrm{N}=28 ; 56 ; 211 ; 77$ 
tend to be less in larger households. This effect was reported by Greer and Thorbecke (1986), and was again demonstrated in the coastal areas in the course of our studies. A decrease of $70 \mathrm{kcal} / \mathrm{cu}$ was estimated for every consumer unit added (Niemeijer, Foeken and Klaver, 1991). In the present case, energy intake per consumer unit in the two groups with the largest farms and the largest households was considerably lower.

A breakdown by origin shows that the lower energy intake in the two latter groups occurred because relatively lesser amounts of food were being purchased. Despite the fact that the large farms had higher incomes and purchased more food in total, the amount was less than the larger households were estimated to require. The differences, however, are greater than can be calculated from existing differences in household size and the rate of $70 \mathrm{kcal} / \mathrm{cu}$, used above. It therefore appears that a negative relation with farm size as such also exists, most likely related to the household economy of the large farms. The latter had higher incomes from cash cropping and also from regular employment but very little or no income from casual labour (Table VII). At first sight this suggests a decrease in women's income, which is known to be important for daily expenditures and food purchases (Quisumbling et al., 1995). Further analysis, however, showed that women's income from employment did not decrease with farm size. This suggests that in this case expenditures on food are related to the flow of income-casual labour is often paid on a daily basis.

Investigation of the relationship with nutritional status is limited to height-for-age because this measure is regarded as the main indicator of long-term influences. The results are in general agreement with those from the food consumption study, although they are less consistent and do not reach statistical significance. Nevertheless, there is a trend that the nutritional status of children on the two grounps of larger farms is generally below that of the two groups of children living on the smaller farms (Table VIII).

\section{CONCLUSION}

Land distribution is an important issue in rural development in Africa. It is generally expected that land distribution will result in increased household income and improvements in nutrition. Many issues, however, remain concerning realization of expected improvements, optimal plot size, management of the schemes, and organization of production. This study has addressed some of these issues by comparing tenant households with rural non-scheme households, and by comparing tenant households owning farms of different sizes. The data on which this paper is based were collected nine years ago, but this fact does not detract from the relevance of the findings. The results of the latest national nutrition survey in 1987 did not show improvements in the coastal districts compared with findings in 1982 (Central Bureau of Statistics, 1983; 1991). There is also no reason to expect that since that time differential changes have affected the groups that were compared in this study.

The first comparison showed that the tenant households were generally better off than the rural households which did not benefit from land distribution, but there is no clear proof that improvement in conditions can be attributed solely to the larger farms as such, because of the equally high differentials in income from off-farm employment. Further analysis by farm size tends to confirm this. There exists such a large differentiation in household economy, in terms of either farming or 
employment, that it is difficult to generalize for the group as a whole. In addition, there are no direct, positive relations between farm size, on the one hand, and household income per consumer unit, food consumption and nutritional status on the other. In fact, the households on the largest farms appear to be less well off than those on the smaller farms. Household size may play an important role here, but also the kind of household economy, that is, combination and deployment of the two main resources, land and labour.

Nevertheless, with respect to the well-being of the tenants, the settlements schemes are a success and the incidence of poverty is far less than among the rural comparison group. Food consumption is greater as well as more varied and the nutritional status of young children is better in the former. These results differ from findings in other settlement schemes elsewhere in Kenya, such as Mwea and Ahero (Korte, 1969; Mwadime, 1989). The latter are schemes with scheduled production of cash crops in which conditions have been found to be poor. It has been noted that tenants who are dependent on one cash crop were in poorest condition (Niemeijer $e t$ $a l ., 1988)$. The present study concerns individual holdings without scheduled production and with limited development assistance. Farmers were largely left to their own initiative; this appears to have worked out quite positively. However, this also means that tenants are left to decide the extent to which they want to develop their farms. Thus, production may well stay below planning expectations, and this has indeed been the case (Hoorweg et al., 1991). This is understandable in view of the following:

Rural households in Kenya generally prefer to diversify their resources. To counter the risks inherent in agriculture, one or more household members will seek some form of wage employment. Meanwhile, crop cultivation safeguards against unemployment and may ease food expenses. The actual balance between the two strategies is decided by external factors such as agro-ecological conditions and employment opportunities, and internal factors such as farm size and available labour in the household. In the case of Coast Province, where agriculture is an uncertain undertaking, it is not surprising that people rely heavily on off-farm employment and, as this study shows, this does not change when they are issued more land. As in the rest of Kenya, people see land not only as a means of production but also as security.

Tenants on settlement schemes where there is no scheduled production do not abruptly change their means of support. They do not maximize agricultural production, and the degree of food self-sufficiency increases only modestly. Higher food consumption is mainly realized by food purchases. In other words, as a strategy, people in this part of Kenya at the time of study preferred to increase their food security through off-farm employment rather than subsistence production, probably not an unwise strategy, all things considered. Elsewhere in Sub-Saharan Africa food purchases also account for an increasing part of the rural diet.

The households with the largest farms are most involved in agriculture but still have sizable incomes from employment and they succeed in achieving the highest incomes. Regrettably, this does not translate into evident increases in food consumption and better nutritional status because of the counteracting influences of family size and changes in household economy which result in lower incomes of women from casual labour, usually the main income used for food purchases.

In his review paper Melville (1988) concluded that land distribution does help to improve the existence of tenants when compared with landless households. But among households owning land there was no evidence of a further relation between 
farm size and family well-being. He concluded that the reason for this had to be sought in the different ways in which people use their land and labour assets. The present paper shows the same findings and relates them further to different household factors.

The question remains why the income from employment is so much higher in the settlement schemes than among the rural population. There are a number of possible reasons. As mentioned earlier there is the group of households with small farms that purchased their farms later but were already chiefly dependent (and continue to be dependent) on income from employment. On the larger sized farms employment income is also higher, however. A reason for this could be that the schemes are situated nearer urban centres with greater employment opportunities, which means not only more employment but also more income that reaches home. However, there are also differences in income from self-employment (much less in casual labour income), and this kind of income is mostly generated on-site or near the home. The greater opportunities for self-employment can only exist if there is greater demand for it from within the community, and this in turn can only be the result of higher incomes overall. In that sense the settlement communities are more economically developed but, as argued above, this can only be partly linked to land ownership and land size. The fact that the households with the largest farms and the highest incomes do not have the most favourable nutritional conditions again confirms the need to include household welfare indicators, such as nutrition, in the assessment of development projects.

\section{ACKNOWLEDGMENTS}

The research reported here was made possible through the cooperation of the Ministry of Planning and National Development, Nairobı, and the African Studies Centre, Leiden, and was funded by the Netherlands Ministry of Development Cooperation The authors wish to acknowledge the contributions of other members of the research team over time Harold van Driel, Marian Geuns, Ted Kliest, Piet Leegwater, Maria Maas and Rudo Niemeijer

\section{REFERENCES}

Boxem, H W, T de Meester and E M A Smalıng (1987) Solls of the Kllifi Area Publication and Documentation Centre, Wageningen

Braun, J von, and E Kennedy, Eds (1994) Agrtcultural Commercialization, Economic Development and Nutrition Johns Hopkins University Press, Baltımore

Central Bureau of Statistics (1983) Third Rural Child Nutrition Survey, 1982 Central Bureau of Statistics, Nairobı

Central Bureau of Statistics (1988) Economtc Survey - 1988 Central Bureau of Statistics, Natrobı

Central Bureau of Statıstics (1991) Fourth Rural Chld Nutrition Survey, 1987 Central Bureau of Statistics, Naırobı

Central Bureau of Statistics (1994) Kenya Population Census, 1989 Volume 1 Central Bureau of Statistics, Nairobi

Chambers, R (1969) Settlement Schemes in Tropical Africa Routledge and Kegan Paul, London

Cooper, F (1981) From Slaves to Squatters Plantation labour and agnculture in Zanzlbar and Coastal Kenya, 1890-1925 Yale University Press/Kenya Literature Bureau, New Haven/Nairobi

Fleuret, P, and A Fleuret (1980) Nutrition, consumption and agricultural change Human Org 39 $250-260$

Foeken, D, and J Hoorweg (1988) Seasonality in the Coastal Lowlands of Kenya Part 2 Introduction to seasonality Food and Nutrition Studies Programme, Report No 28, Ministry of Planning and National Development/African Studıes Centre, Nairobı/Leiden

Foeken, D , P Leegwater, R Niemeijer, W Veerman and J Hoorweg (1989) Seasonality in the Coastal Lowlands of Kenya Part 3 Socio-economic Profile Food and Nutrition Studies Programme, Report No 32, Minıstry of Planning and Natıonal Development/African Studıes Centre, Nairobi/Leiden 
Government of Kenya (1986) Sessional Paper No I on Economic Management for Renewed Growth Government of Kenya, Narrob1

Greer, J, and E Thorbecke (1986) Food Poverty and Consumption Patterns in Kenya International Labour Office, Geneva

Herlehy, T J (1984) An Historical Dimension of the Food Crisis in Africa Surviving famines along the Kenya Coast, ca 1880-1980 Workıng Paper no 87, African Studies Centre, Boston Unıversity, Boston, Mass

Heyer, J, and J K Waweru (1976) The development of small farm areas In J Heyer, J Matha and W Senga (Eds), Agricultural Development in Kenya An economic assessment Oxford University Press, Nairobi pp 187-221

Hınderınk, J, and J J Sterkenburg (1986) Agricultural Commercialısation and Goverment Polıcy in Africa Kegan Paul International, London

Hoorweg, J, Ed (1993) FNSP studtes, 1985-1992 Results and Recommendattons Food and Nutrition Studies Programme, Report No 50, Ministry of Planning and Natıonal Development/African Studies Centre, Nairobı/Leiden

Hoorweg, J, T Kliest and R Niemejer (1988) Seasonality in the Coastal Lowlands of Kenya Part I Research objectives and study design Food and Nutrition Studies Programme, Report No 27, Minıstry of Planning and Natıonal Development/African Studies Centre, Nairobı/Leiden

Hoorweg, J, R Niemeijer, D Foeken, W Okello and W Veerman (1991) Economic and Nutritional Conditions at Settlement Schemes in Coast Province Food and Nutntion Studres Programme, Report No 36, Minıstry of Planning and Natıonal Development/African Studies Centre, Naırobı/Leiden

Jaetzold, R, and H Schmidt (1983) Farm Management Handbook of Kenya, Volume II Natural conditions and farm management information, Part C East Kenya Ministry of Agriculture, Nairobi

Jazairy, I, M Alamgir and T Panuccio, Eds (1992) The State of World Rural Poverty An inquiry into its causes and consequences (Published for the International Fund for Agricultural Development) New York University Press, New York

Kliest, T (1985) Regional and Seasonal Food Problems in Kenya Food and Nutrition Studies Programme, Report No 10, Minıstry of Plannıng and National Development/African Studies Centre, Narrob1/Leiden

Korte, R (1969) The nutritional and health status of the people living in the Mwea-Tebere irrigation settlement In $\mathrm{H}$ Kraut and H D Cremer (Eds), Investigations into Health and Nutrtton in East Africa Weltforum, Munchen pp 267-334

Leegwater, P, J Ngolo and J Hoorweg (1991) Nutrition and Datry Development in Ktltfi District Food and Nutrition Studies Programme, Report No 35, Ministry of Planning and National Development/African Studies Centre, Nairobi/Leiden

Leys, C (1975) Underdevelopment in Kenya The polttical economy of neo colonialism, 1964-197I Heinemann, London

Maas, M and N van Hekken (1991) Women's Social and Economic Projects Experiences from Coast Province Food and Nutrition Studies Programme, Report No 37, Ministry of Planning and National Development/African Studies Centre, Nairobi/Leiden

Melville, B F (1988) Are land avalability and cropping patterns critical factors in determining nutritional status? Food Nutr Bull 10, $44-48$

Ministry of Environment and Natural Resources (1984a) Killfi District Environmental Assessment Report Ministry of Environment and Natural Resources, Nairobi

Ministry of Environment and Natural Resources (1984b) Kwale District Envtronmental Assessment Report Ministry of Environment and Natural Resources, Narrobı

Mwadime, R K (1989) Expenditure, Food Consumption Patterns and Nutritional Status of Tenants in a Rice Irrigation Scheme, Kenya M Sc thesis, Department of Food Technology and Nutrition, University of Nairobı

Niemeıjer, R, M Geuns, T Klıest, V Ogonda and J Hoorweg (1988) Nutrition in agricultural development The case of irrigated nce cultivation in West Kenya Ecol Food Nutr 22, 65-81

Niemeijer, R, D Foeken and W Klaver (1991) Seasonality in the Coastal Lowlands of Kenya Part 4/5 Food consumption and anthropometry Food and Nutrition Studies Programme, Report No 38, Minıstry of Planning and National Development/African Studies Centre, Nairobi/Leiden

Oosten, C van (1989) Farming Systems and Food Securtty in Kwale District, Kenya Food and Nutrition Studies Programme, Report No 30, Ministry of Planning and Natıonal Development/African Studies Centre, Nairobi/Leiden

Peters, C, and R Niemeıjer (1987) Protein-energy Malnutrition and the Home Environment A study among children in Coast Province, Kenya Food and Nutrition Studies Programme, Report No 22, Minıstry of Planning and National Development/African Studies Centre. Nairobı/Leiden

Pinstrup-Andersen, P (1985) The impact of export crop production on human nutrition In M Biswas and P Pinstrup-Andersen (Eds ), Nutrition and Development Oxford University Press, Oxford pp 43-59 
Platt, B. S. (1962). Tables of Representative Values of Foods Commonly Used in Tropical Countries (revised ed.). Medical Research Council Special Report No. 302. Her Majesty's Stationery Office, London.

Quisumbling, A. R, L. R. Brown, H. S. Feldstein, L. Haddad and C. Pena (1995). Women: The key to food security. Food Policy Report, International Food Policy Research Institute, Washington.

Ruigu, G. M. (1987). Large-Scale Irrigation Development in Kenya: Past performance and future prospects. Food and Nutrition Studies Programme, Report No. 23, Ministry of Planning and National Development/African Studies Centre, Nairobi/Leiden.

Salim, A. I. (1973). Swahili Speaking Peoples of Kenya's Coast 1885-1965. East African Publishing House, Nairobi.

Spear, T. T. (1978). The Kaya Complex: A history of the Mijikenda peoples of the Kenya coast to 1900. Kenya Literature Bureau, Nairobi.

UNICEF (1984). Situation Analysis of Children and Women in Kenya, Volume 4: The well-being of children. Central Bureau of Statistics/UNICEF, Nairobi.

Waaijenberg, H. (1993). Land and Labour in Mijikenda Agriculture, Kenya, 1850-1985. Research Report No. 53. African Studies Centre, Leiden.

Waaijenberg, H. (1994). Mijikenda Agriculture in Coast Province of Kenya: Peasants in between tradition, ecology and policy. (Ph. D. thesis, University of Wageningen). Royal Tropical Institute, Amsterdam

WHO (1983). Measuring Change in Nutritional Status: Guidelines for assessing the nutritional impact of supplementary feeding programmes for vulnerable groups. World Health Organization, Geneva.

WHO (1985). Energy and Protein Requirements. Technical Report 724, World Health Organization, Geneva. 